\title{
Effect of Tenderization, Meat Restructuring and Cutting Technique on the Texture of Dried Beef
}

\author{
DILIP SUBBA*
}

\author{
Central Campus of Technology, Tribhuvan University, Dharan, Nepal
}

The effect of tenderization treatments and meat restructuring on the texture of dried beef was investigated. Beef topside and eye of round were cut across and along the grain direction in thin strips and tenderized by blade tenderization and papain treatment. Yet another portion of meat was restructured. The meat was dried in hot air $\left(50^{\circ} \mathrm{C}\right)$ to $70 \%$ weight loss. Shear force of the rehydrated dried muscles was measured by Instron Universal Testing Machine. The dried meat which was tenderized before drying showed low shear force value than the non-tenderized control samples $(p<0.05)$. Also lower shear force values were obtained for the dried meat which was cut across the grain than cut along the grain.

Keywords: Tenderization methods, Restructuring, Cutting methods, Texture, Dried beef

\section{Introduction}

In many parts of the world drying is practiced as a method of meat preservation since antiquity. Shelf stable type of dried meat with very low moisture content is prepared by traditional methods in countries particularly of Asia, Africa and Latin America. Drying to very low moisture content is advantageous from preservation point of view as the product has long shelf life alone by virtue of low moisture content and water activity. Traditionally the meat is dried by sun, air, heat of burning fuel wood or charcoal and so on. Now days, solar dryers are being increasingly used. The meat may be salted and spiced or cooked before drying. An account of the traditional preparation of dried meat in different countries can be found in the literature (Obanu 1988; FAO 1990).

The dry meat may be eaten as such as snack or after marinating with seasoning and tomato juice. Lot of dry meat is cooked before serving. It may be reconstituted in hot water before cooking or it can be added in the cooking vessel without prior reconstitution and braised. It may also be pan-fried in oil. Texture is one of the important quality attributes of meat. It is unquestionable that a tender meat is much more acceptable than a tough meat. Meat dried to very low moisture content is tough. There is a challenge to prepare tender dry meat. A number of meat tenderization methods have been described in literature such as blade tenderization (Hayward et al., 1980; Shakelford et al., 1989), enzymatic tenderization with protease enzyme of plant origin such as papain, bromelin, ficin, ginger rhizome protease and actidin (Dawson and Wells 1969; Lewis and Luh 1988) and microbial origin like bacterial collagenase (Foegeding and Lrick 1986; Miller et al., 1989) and protease from Trichoderma reesei (Robbins et al., 1986) and rennet (Cronlund and Woychik 1986). Blade tenderization and tenderization by proteolytic enzymes already have been

*Corresponding author, E-mail: dilipsubba2009@yahoo.com commercially used for the tenderization of meat and poultry. It is worth of investigation whether tenderization of meat before drying will have effect on the texture of dry meat or not. This study was undertaken to investigate the effect of blade tenderization, enzymatic tenderization by papain and meat restructuring and further, the effect of cutting meat along or across the grain direction on the tenderness of dried beef.

\section{Materials and Methods}

Beef topside and eye of round were obtained from the local slaughterhouse of Stuttgart, Germany and deep-chilled. Each muscle was divided in two equal portions. One portion was cut along the grain i.e. in fibre direction and another across the grain i.e. perpendicular to fibre direction. The meat was cut with a meat slicing machine into 10-12 cm long strips of 5 $\mathrm{mm}$ thickness and $1.9 \mathrm{~cm}$ width. Thus prepared meat strips were then subjected to the following treatments:

Blade tenderization: a heavy steel hammer containing sharpedged teeth on the head was used for blade tenderization. Its head measured $2.4 \mathrm{~cm} \times 3 \mathrm{~cm}$ and the teeth were aligned in 4 rows and 4 columns in the head with every row containing 4 teeth. The distance between two rows was $0.7 \mathrm{~cm}$. The hammer was used to strike the meat on both sides such that the teeth punctured the meat strip- 8 punctures per sq $\mathrm{cm}$.

Tenderization by papain enzyme: purified papain powder produced from Carica papaya with an activity of 30000 USP/ mg obtained from Gewürzmüller GmbH, Stuttgart, Germany was used for this treatment. The meat strip was immersed in hot $\left(60^{\circ} \mathrm{C}\right) 0.01 \%$ papain solution for $30 \mathrm{~min}$ and drained.

Restructuring: The meat left as remainder after blade tenderization and papain enzyme treatment was ground by passing through a 3-mm plate of meat grinder (Maschinenfabrik Sydelmann KG, Stuttgart, Germany). To this, salt $2 \%$ by weight was added and mixed for $2 \mathrm{~min}$ in a kitchen 
mixer (Hobart Corporation, Ohio, USA) for proper binding. The ground meat was filled, pressed and formed in rectangular metallic moulds. The resulting meat bar measured $1.9 \mathrm{~cm}$ wide and $5 \mathrm{~mm}$ thick.

The blade tenderized, papain treated meat strips and the restructured meats (bar) were dried in a hot air dryer at $50^{\circ} \mathrm{C}$ to a weight loss of $70 \%$. Before texture measurement the samples were steeped in hot water $\left(82^{\circ} \mathrm{C}\right)$ for 1 hour. The shear forces of non-tenderized, raw and dried meat samples (control) and tenderized, dried meat samples were measured by Instron Universal Testing Machine 1011 (Fa. Instron, Karlstein, Germany) aided by Instron Series IX Automated Materials Testing System software, version 5 (1990 Instron Corporation). A $7.5 \mathrm{~cm}$ wide and $1.2 \mathrm{~mm}$ thick sharp edged blade was lowered onto the sample at crosshead speed of 100 $\mathrm{mm} / \mathrm{min}$ and the maximum shear force (Newton) was measured. 10 meat strips or meat bars from each treatment were taken for shear force measurement and each sample was sheared at three different positions.

Statistical analyses: The hardness data were analyzed by General Linear Model procedure of the SAS computing package at $(\mathrm{p}<0.05)$ level of significance.

\section{Results and Discussion}

Mean shear force (Newton) of tenderized, restructured and non-tenderized raw beef muscle eye of round and topside cut across and along the grain are shown in Table 1 and 2 respectively. All treatments decreased the shear force of meat. Increase in the tenderness of beef steak by blade tenderization is already established (Hayward et al., 1980; Shakelford et al., 1989). Shakelford et al., (1989) found significant decrease in the hardness of blade tenderized chuck roast.
The papain treatment resulted in much tender meat than blade tenderization. Grinding meat as essential process for restructuring could show much more profound effect on tenderness of meat. The grinding can be proposed as a process to completely destruct the meat structure leading to fineness and destruction of connective tissue with net result in offer of less resistance to shear. Further more, the effect of cutting technique could be clearly observed. A significant difference in the shear force was observed between the meat cutting techniques by cutting across the grain direction and along the grain. This difference was observed in both the muscle type under investigation and this may suggest that similar effect can be seen in all muscle types.

In general pre-tenderized dried muscles were found to be significantly more tender $(\mathrm{p}<0.05)$ compared to non-tenderized dried muscles. The cutting technique was found decisive for the degree of toughness or tenderness of dried meat. Low shear force was recorded for the meat cut across the grain than the meat cut along the grain. This was true for both muscles and for both of tenderization treatments. Difference in the shear force values between papain treatment and blade tenderization depended on cutting technique. The muscles cut across the grain and tenderized by papain enzyme treatment yielded shear force value lower than blade tenderization. The shear force values did not differ significantly among the treatments for the meat cut along the grain. Interestingly, drying tremendously increased the toughness of restructured meat. If it was due to compacting of meat, random arrangement of muscle fibers and increase in cohesiveness remains to be investigated.

Table 1. Mean shear force (Newton) of tenderized and non-tenderized raw beef muscle eye of round

\begin{tabular}{lllll}
\hline Cutting technique & \multicolumn{1}{c}{$\begin{array}{c}\text { Blade } \\
\text { tenderization }\end{array}$} & \multicolumn{2}{c}{ Treatment* } \\
\cline { 2 - 5 } Across grain & $55.33^{\mathrm{a}, \mathrm{b}}$ & $34.10^{\mathrm{a}, \mathrm{b}}$ & $4.80^{\mathrm{a}}$ & $70.05^{\mathrm{a}, \mathrm{b}}$ \\
Along grain & $67.43^{\mathrm{a}, \mathrm{b}}$ & $77.59^{\mathrm{a}, \mathrm{b}}$ & $4.80^{\mathrm{a}}$ & $82.77^{\mathrm{a}, \mathrm{b}}$ \\
\hline
\end{tabular}

${ }^{a}$ Means in the same row with the same superscript are significantly different $(\mathrm{p}<0.05)$

${ }^{\mathrm{b}}$ Means in the same column with the same superscript are significantly different $(\mathrm{p}<0.05)$

Table 2. Mean shear force (Newton) of tenderized and non-tenderized raw beef muscle topside

\begin{tabular}{|c|c|c|c|c|}
\hline \multirow{2}{*}{ Cutting technique } & \multirow{2}{*}{$\begin{array}{l}\text { Blade } \\
\text { tenderization }\end{array}$} & \multicolumn{3}{|c|}{ Treatment } \\
\hline & & Papain treatment & Restructuring & Non-tenderized (control) \\
\hline Across grain & $50.90^{\mathrm{a}, \mathrm{b}}$ & $34.11^{\mathrm{a}, \mathrm{b}}$ & $3.20^{\mathrm{a}}$ & $36.87^{\mathrm{a}, \mathrm{b}}$ \\
\hline Along grain & $41.32^{\mathrm{a}, \mathrm{b}}$ & $39.43^{\mathrm{a}, \mathrm{b}}$ & $3.20^{\mathrm{a}}$ & $44.87^{\mathrm{a}, \mathrm{b}}$ \\
\hline
\end{tabular}

${ }^{\mathrm{a}}$ Means in the same row with the same superscript are significantly different $(\mathrm{p}<0.05)$

${ }^{\mathrm{b}}$ Means in the same column with the same superscript are significantly different $(\mathrm{p}<0.05)$ 
Table 3 and 4 show the mean shear force values of pre-tenderized dried and non-tenderized dried beef muscles.

Table 3. Mean shear force (Newton) of pre-tenderized dried and non-tenderized dried (control) beef muscle eye of round

\begin{tabular}{|c|c|c|c|c|}
\hline \multirow[b]{2}{*}{$\begin{array}{l}\text { Cutting } \\
\text { technique }\end{array}$} & \multirow[b]{2}{*}{ Blade tenderization } & \multicolumn{3}{|c|}{ Treatment } \\
\hline & & $\begin{array}{c}\text { Papain } \\
\text { treatment }\end{array}$ & Restructuring & $\begin{array}{c}\text { Non-tenderized } \\
\text { (control) }\end{array}$ \\
\hline Across grain & $68.40^{\mathrm{a}, \mathrm{c}}$ & $47.26^{\mathrm{a}, \mathrm{c}}$ & $115.90^{\mathrm{a}}$ & $93.42^{\mathrm{a}, \mathrm{c}}$ \\
\hline Along grain & $96.84^{\mathrm{a}, \mathrm{b}, \mathrm{c}}$ & $101.78^{a, b, c}$ & $115.90^{\mathrm{a}}$ & $174.06^{\mathrm{a}, \mathrm{c}}$ \\
\hline
\end{tabular}

Table 4. Mean shear force (Newton) of pre-tenderized dried and non-tenderized dried (control) beef muscle topside

\begin{tabular}{clllc}
\hline \multirow{2}{*}{$\begin{array}{c}\text { Cutting } \\
\text { technique }\end{array}$} & Blade tenderization & \multicolumn{3}{c}{ Treatment } \\
\cline { 3 - 5 } & & \multicolumn{1}{c}{$\begin{array}{c}\text { Papain } \\
\text { treatment }\end{array}$} & Restructuring $^{\text {a,c }}$ & $\begin{array}{c}\text { Non-tenderized } \\
\text { (control) }\end{array}$ \\
\hline Across grain & $67.35^{\mathrm{a}, \mathrm{c}}$ & $46.70^{\mathrm{a}, \mathrm{c}}$ & $90.59^{\mathrm{a}, \mathrm{b}}$ & $89.28^{\mathrm{a}, \mathrm{b}, \mathrm{c}}$ \\
Along grain & $80.13^{\mathrm{a}, \mathrm{b}, \mathrm{c}}$ & $93.50^{\mathrm{a}, \mathrm{b}, \mathrm{c}}$ & $90.59^{\mathrm{a}, \mathrm{b}}$ & $115.35^{\mathrm{a}, \mathrm{c}}$ \\
\hline
\end{tabular}

${ }^{a}$ Means in the same row with the same superscript are significantly different $(\mathrm{p}<0.05)$

${ }^{\mathrm{b}}$ Means in the same row with the same superscript are not significantly different $(\mathrm{p}<0.05)$

${ }^{\mathrm{c}}$ Means in the same column with the same superscript are significantly different $(\mathrm{p}<0.05)$

\section{Conclusion}

Blade tenderization and papain treatment to beef muscles significantly increased $(p<0.05)$ the tenderness of dried beef. Therefore, these tenderization treatments can be recommended for the preparation of tender dried meat. Additionally, restructuring by grinding and forming meat is no solution to produce tender dried meat.

\section{Acknowledgements}

The author wishes to express gratitude to Gewürzmüller $\mathrm{GmbH}$, Stuttgart, Germany for making available papain enzyme and Prof. Dr. Albert Fischer and Kurt Herrmann of the Institute of Food Technology, University of Hohenheim, Stuttgart, Germany for providing laboratory facilities and generous support for completing this study.

\section{References}

Cronlund A. L. and Woychik J. H. (1986). Effect of microbial rennets on meat protein fractions. J. of Agri. and Food Chem., 34(3): 502-505.

Dawson L. E. and Wells G. H. (1969). Tenderness of freezedried chicken treated with proteolytic enzymes. Poultry Sci., 48(1): 64-70.

FAO (1990). Manual on simple methods of food preservation. FAO Animal Production and Health paper 79. FAO, Rome.

Foegeding E. A. and Larick D. K. (1986). Tenderization of beef with bacterial collagenase. Meat Sci., 18(3): 201-214.

Hayward L. H., Hunt M. C., Kastner C. L. and Kropf D. H. (1980). Blade tenderization effects on beef longissimus sensory and instron textural measurements. J. of Food Sci., 45: 925-930.

Lee Y. B., Sehnert D. J. and Ashmore C. R. (1986). Tenderization of meat with ginger rhizome protease. J. of Food Sci., 51(6): 1558-1559.

Lewis D. A. and Luh B. S. (1988). Application of actinidin from kiwifruit to meat tenderization and characterization of beef muscle protein hydrolysis. J. of Food Biochem., 12(3): 147-158.

Miller A. J., Strange E. D. and Whiting R. C. (1989). Improved tenderness of restructured beef steaks by a microbial collagenase derived from Vibrio B-30. J. of Food Sci., 54(4): 855-857.

Obanu Z. A. (1988). Preservation of meat in Africa by control of the internal aqueous environment in relation to product quality and stability. In: Preservation by moisture control. Elsevier Applied Science, New York and London, pp 163167.

Robbins F. M., Allen A. L., Walker J. E. and Cohen S. H. (1986). Meat tenderization with a proteolytic enzyme from Trichoderma reesei. United States Patent. PN: US 4600 589(US4600589).

Shackelford S. D., Reagan J. O., Mann T. F., Lyon C. E. and Miller M. F. (1989). Effects of blade tenderization, vacuum massage time and salt level on chemical, textural and sensory characteristics of precooked chuck roasts. $J$. of Food Sci., 54(4): 843-845, 905. 